\title{
A review chromosome analysis comparison of swamp buffalo (Bubalus bubalis) with different phenotypic characters in East Java, Indonesia
}

\author{
Ardyah Ramadhina Irsanti Putri ${ }^{1}$, Gatot Ciptadi $^{1{ }^{1}{ }^{*}, \text { Agus } \text { Budiarto }^{1} \text {, Sri Rahayu }}{ }^{2}$, Helly \\ Nurul Karima ${ }^{3}$, Susiati ${ }^{4}$, Perdana Finawati ${ }^{4}$, Mudawamah ${ }^{5}$, and Yudit Oktanella ${ }^{6}$ \\ ${ }^{1}$ Faculty of Animal Science, Brawijaya University, 65145 Malang, Indonesia \\ ${ }^{2}$ Faculty of Mathematics dan Science, Biology Department, Brawijaya University, 65145 Malang \\ Indonesia \\ ${ }^{3}$ Central laboratoium (LSIH), Brawijaya University, 65145 Malang, Indonesia \\ ${ }^{4}$ Biosains Institute, Brawijaya University, 65145 Malang, Indonesia \\ ${ }^{5}$ Faculty of Animal Husbandry, Islamic University of Malang, 65144 Malang, Indonesia \\ ${ }^{6}$ Faculty of Veterinary Medicine, Brawijaya University, 65145 Malang, Indonesia
}

\begin{abstract}
Chromosomal data on swamp buffalo especially in East Java province, is still lacking. For breeders, chromosomal analysis needs to be done to detect the possibility of hereditary genetic defects. In Malang Area, farmers lack of care and breeding programs for swamp buffalo also caused a decline in the genetic quality and performance. The purpose of this study was to compare the results of the chromosome analysis of swamp buffalo in Malang and another area in East Java province, which were selected based on differences in phenotypic characters. Chromosome analysis is very important for breeders because the results of this study can be used as a consideration for strategies to improve the genetic quality of swamp buffalo. The method used is standard karyotyping using whole blood with $\mathrm{G}$ banding staining. Chromosomal preparation using Karyo MAX medium, Colcemic Solution, Giemsa Stain, and $\mathrm{KCl}$ solution. Cell culture was performed according to the standard karyotyping method in mammals. The minimum number of 5 spreading chromosomes is the best was chosen, microphotographed, and then chromosome analysis is performed using Cytovision Image Analysis software. The results of this study did not find swamp buffalo with an abnormal number of chromosomes in East Java Province, Indonesia.
\end{abstract}

\section{Introduction}

Most of the livestock animals in Indonesia are categorized as a non-identified breed and practically have no sufficient genetic quality information, pedigree, lower productivity, and limited recording availability. There is still limited research that studies local Indonesian livestock Animals, especially buffalo, based on the information or data of cellular and

\footnotetext{
*Corresponding author: ciptadi@ub.ac.id
} 
molecular [1]. Analysis of the history and origins of local Indonesian animals, especially local buffalo (swamp buffalo), are still compiled and described mainly based on information on phenotypic characters. This condition occurs because almost all of the buffalo are kept traditionally by small farmers in the countryside, not yet raised for commercial purposes. Buffalo farming faces serious problems because the population is decreasing by $3 \%$ per year due to the availability of specific habitats for buffalo, which is getting narrower. Genetic analysis at the molecular and cellular level needs to be done through chromosome analysis, which can reportedly be used as a device for identifying and tracking animal origins [2].

Indonesia has high animal biodiversity, one of which is ruminant livestock, namely swamp buffalo. The main type of buffalo in Indonesia is the swamp buffalo, which varies phenotypically; the hair or skin colour includes black, greyish, reddish, and white, or their body condition score (BCS) [3]. The cause of this variation is not known with certainty, whether due to hormonal problems, feed conditions, climatic influences, or other causes. It is essential to preserve genetic resources to maintain and improve the quality of phenotypic and genotyping continuously so that breeds can survive [4]. The purpose of this study was to identify the swamp buffalo in Indonesia based on the emergence of the profile of the chromosome base on the varieties of phenotypic character.

\section{Materials and methods}

\subsection{Animals}

The livestock used in this study were taken from several places the East Java region, where male buffaloes / bulls were found by showing phenotypic variations in coat and skin color, located in Malang district, Sumenep, and Kangean Island. It was taken by purposive sampling of buffalo with red, white, and blackish grey skin color, which every different color taken one whole blood sampling. This Swamp buffalo in Malang and another area in East Java province were selected based on differences and variation in phenotypic characters.

\subsection{Chromosome analysis and karyotyping}

The method used is standard karyotyping using whole blood with G-banding staining. Chromosomal preparation using Karyo MAX medium (GIBCO/BRL), Colcemic Solution, Giemsa Stain, and $\mathrm{KCl}$ (Potassium chloride) solution. Cell culture was performed according to the standard karyotyping method in mammals. The minimum number of 5 spreading Metaphase II chromosomes is the best was chosen, microphotography is performed, and then chromosome analysis is performed using Cytovision Image Analysis software.

\section{Results and discussion}

\subsection{Animals with phenotypic traits that deviate from the standard}

Swamp buffaloes selected for chromosomal analysis were characterized by phenotypic deviations of fur or skin color from the standard blackish gray colour, known from 4 regions, namely Sumenep, Kangean Island, Malang, and Banyuwangi. In general, the productivity of the swamp buffalo in East Java varies greatly. The color aberrations include red (Kangean Island), White (Kangean Island and Sumenep district), and blackish grey 
colour (Malang district). Black was excluded from the chromosome analysis because it was later discovered that the black colour of buffalo on Kangean Island was used as a buffalo contest and race. The breeder makes it during the Buffalo race (Fig. 1).
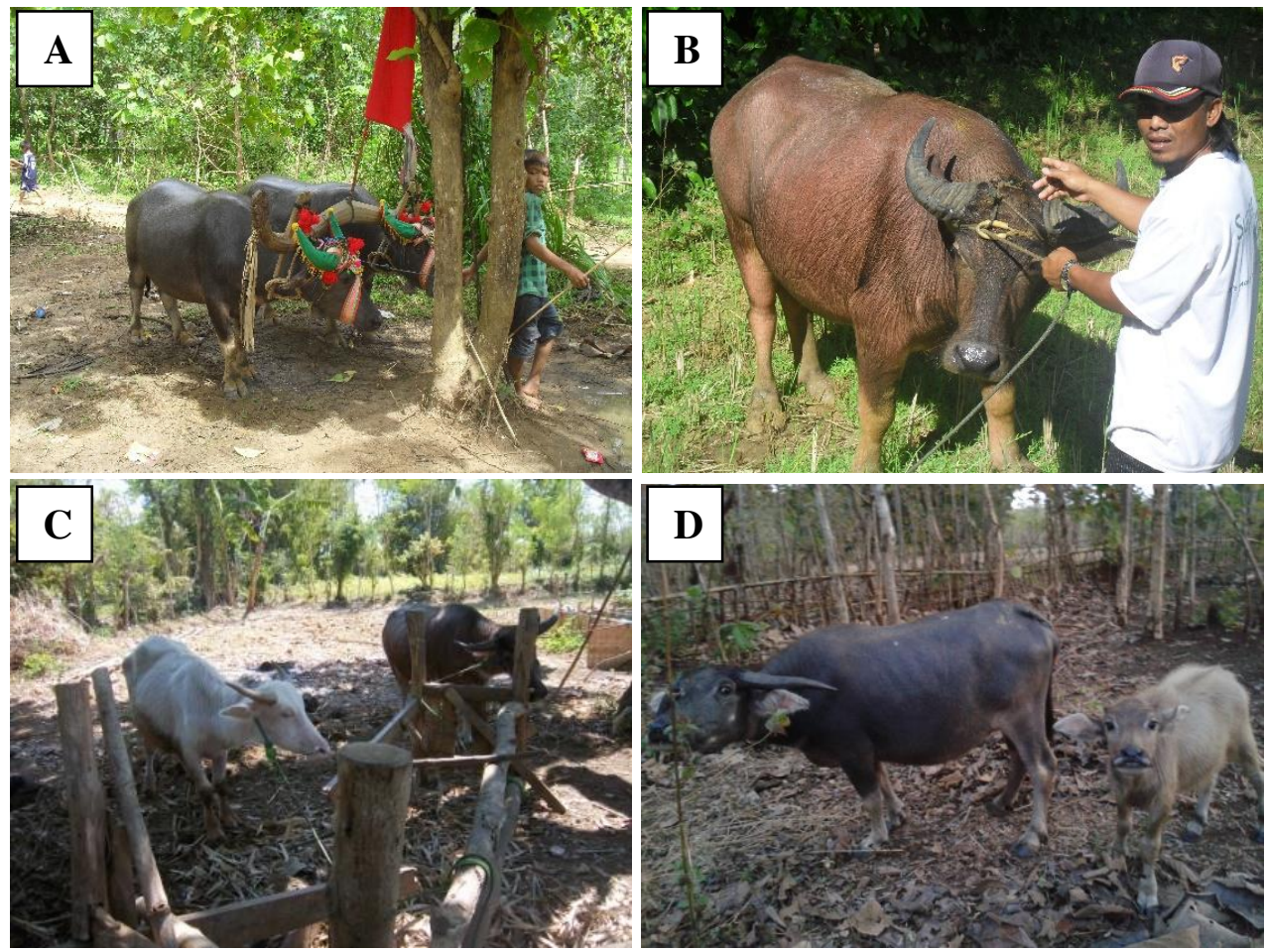

Fig. 1. Variations in fur/skin color are found in the fields; (A) Kangean Island, (B,C) Sumenep, and (D) Malang

Previous research results, we interviewed community leaders on Kangean Island, the incidence or frequency of the appearance of this white or fur-coloured buffalo is quite high, several or even dozens on Kangean Island, but then decreased because it is said that these buffaloes were sacrificed for ceremonies [5]. Certain traditional or religious events in Kangean Island Square. Currently, there are only three white buffalo left, while the red ones are increasing in number. Swamp buffalo with white hair color abnormality was also found in some young calves [6], for example, in Malang and Ngawi regencies, but then changed to normal as they got closer to sexual maturity; this is thought to be due to hormonal factors.

\subsection{Chromosome analysis of swamp buffalo}

The chromosomes are considered normal or abnormal based on standard karyotyping. The results of this study did not find swamp buffalo with an abnormal number of chromosomes, so it could be interpreted that there was no chromosomal abnormality from a phenotypic comparison of swamp buffalo in East Java Province, Indonesia. The results of the preparation of the chromosomes of the swamp buffalo using the Giemsa staining technique (G-banding standard) resulted in a fairly good spreading so that it was possible to calculate the number of chromosomes easily [7]. The results of the analysis showed that both 
buffaloes with normal blackish grey skin colour, or those with reddish-grey and white skin colour, showed a normal number of chromosomes, as many as 48 chromosomes. The results of the karyotyping analysis, when compared with the existing standards, both body and sex chromosomes, also showed normal results [8,9]. Red and white buffalo on Kangean Island and Sumenep, Madura also showed a normal number of chromosomes [9]. Also in previous study have done chromosome analysis of PE and Senduro goats and found that the X-Y chromosomes of the two goat breeds did not differ based on the morphological shape of the chromosomes [11].

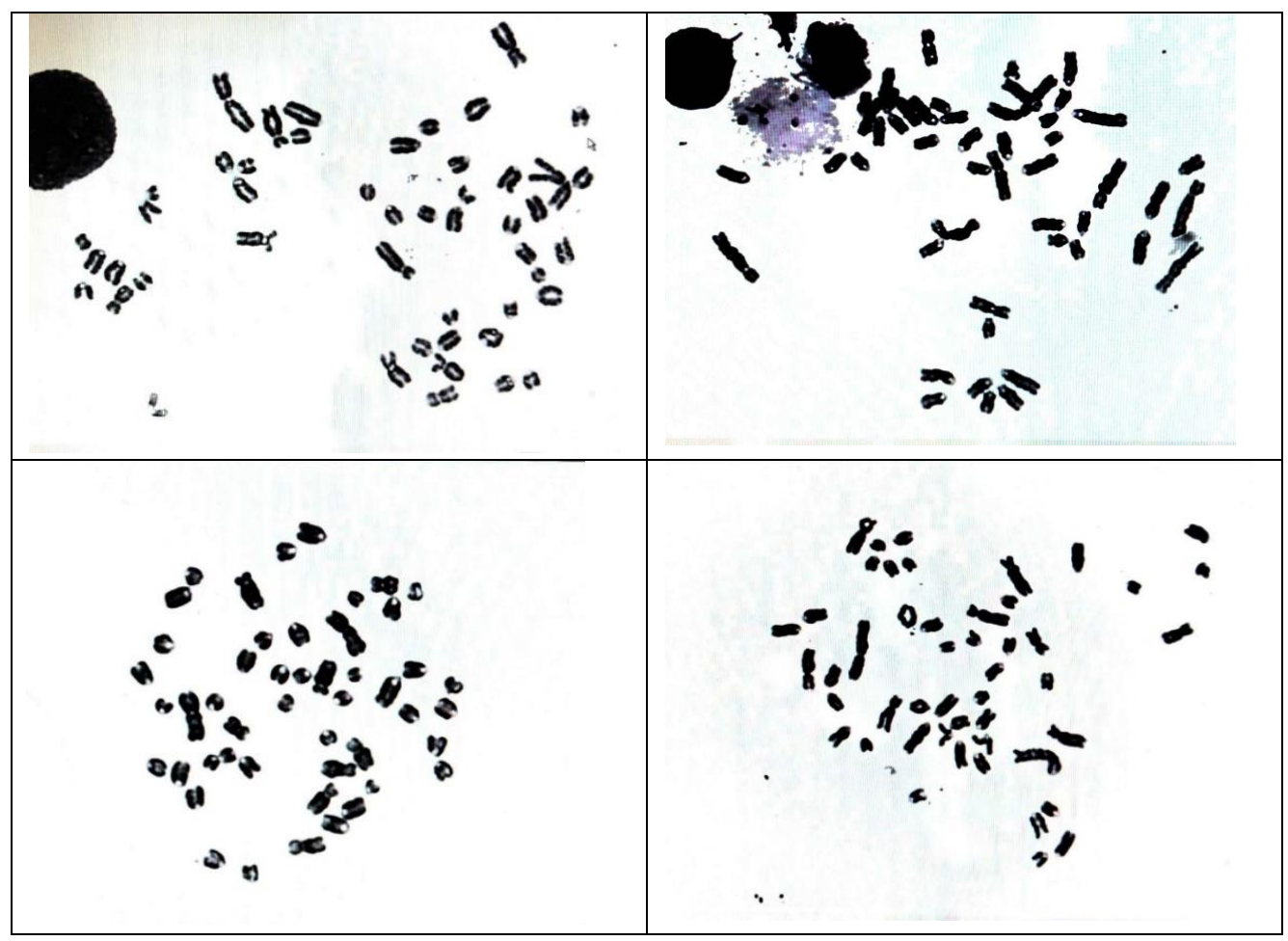

Fig. 2. The results of karyotyping of East Java swamp buffalo with various phenotypic variations that show genetically normal results

The results of the preparation of the chromosomes of the swamp buffalo using the Giemsa staining technique (G-banding standard) resulted in a fairly good spreading so that it was possible to calculate the number of chromosomes easily. The results of the analysis showed that both buffaloes with normal blackish grey skin colour, or those with reddishgrey and white skin colour, showed a normal number of chromosomes, as many as 48 chromosomes. The results of the karyotyping analysis tested in this research were normal categories. The karyotype analysis showed that the chromosomes of one cell and different individuals in each breed varied in the centromere's size, shape, and position. The standard chromosomal preparation technique for buffalo with $\mathrm{G}$ banding still needs to be improved to obtain better chromosome spreading results and facilitate detailed karyotyping. It seems necessary to suggest molecular studies to prove the possibility of mutations in skin colour control genes [12]. Based on genetic analysis based on the number of chromosomes from this study are that all swamp buffalo have a normal genetically. Further research needs to 
be done using other staining techniques such as R-banding or even FISH (Florescent In Situ Hybridization) to obtain better and specific karyotyping results.

\section{Conclusion}

The conclusion of this study did not find swamp buffalo with an abnormal number of chromosomes $(2 \mathrm{~N}=48)$, so it could be interpreted that there was no chromosomal abnormality in their number based from a phenotypic comparison of swamp buffalo in East Java Province, Indonesia.

This research is part of research on Analysis of Local genetic Animals funded by the grant from Brawijaya University of HPU (Hibah Penelitian Unggulan) 2021 Grant, No.r: 023.17.2.677512/2021. I wish to thank all young assistance researchers, especially Helly Nurul Karima, Dinda H.K. Wijaya, Ardyah Ramadhina I. P., who is involved and works preparing chromosome analysis in most of the work is related

\section{References}

1. G. Ciptadi, A Budiarto, M Nasich, Mudawamah, S Rahayu, Dyah Ayu O. A.P, A I Putri, H N Karima, Y Oktanella, Y Saynandya and R G Almaida, IOP Conference Series: Earth and Environmental Science, 743 (2020)

2. R. Parada, M. Kawka, M. Sacharczuk, P. Urbański, K. Jaszczak, J. Biol Sci., 7 (2017)

3. G. Ciptadi, M Nasich, A Budiarto, V.M.A. Nurgiartiningsih. Pakistan Veterinary Journal, 32 (2012)

4. A Budiarto, G Ciptadi, M Nasich, and Fatich, IOP Conf. Series: Earth and Environmental Science, $\mathbf{4 7 8}$ (2020)

5. G. Ciptadi, M. Mudawamah, V.M.A. Nurgiartiningsih, S. Wahjuningsih, Rr. F. D. Listiani, Susiati, L. Hakim, and A. Budiarto, AIP Conference Proceedings 2021, 070009 (2018)

6. A. Budiarto, G. Ciptadi, L. Hakim, Susiati, N.K. Karima, M.H. Hisam, IOP Conf. Series: Earth and Environmental Science, 247 (2019)

7. A.R.I. Putri, G. Ciptadi, A.P. Warih, IOP Conference Series: Earth and Environmental Science, 119 (2018)

8. A Budiarto, L Hakim, G. Ciptadi, M. Nasich, A.R.I. Putri, N.K. Karima, Y..D..A Prasetyo, IOP Conference Series: Earth and Environmental Science, 743 (2021)

9. G. Ciptadi, M.N. Ihsan, V.M.A. Nurgiartiningsih, I.P. Ardyah, A. Budiarto and Mudawamah, Biodiversitas Journal of Biological Diversity, 18 (2017).

10. G. Ciptadi, A. Budiarto, M. Nasich, Mudawamah, S. Rahayu, D. Ayu, A.I. Putri, H.N. Karima, Y. Oktanella, Y. Saynandya and RG Almaida, IOP Conference Series: Earth and Environmental Science, 743 (2020)

11. G. Ciptadi, M.N. Ihsan, S. Rahayu, V.M.A. Nurgiartiningsih, Mudawamah, and A.R.I. Putri, Research Journal Of Life Science, 4 (2017)

12. Mudawamah, I. Ratnaningtyas, M. Fadli, G. Ciptadi, Journal of Physics: Conference Series, 1146 (2019) 